(C) The Author(s), 2020. Published by Cambridge University Press on behalf of The Nutrition Society. This is an Open Access article, distributed under the terms of the Creative Commons Attribution licence (http://creativecommons.org/licenses/by/4.0/), which permits unrestricted re-use, distribution, and reproduction in any medium, provided the original work is properly cited.

\title{
Nutrigenetics of antioxidant enzymes and micronutrient needs in the context of viral infections
}

\author{
Ruth Birk (1) \\ Department of Nutrition, Faculty of Health Sciences, Ariel University, Ariel, Israel
}

\section{Abstract}

Sustaining adequate nutritional needs of a population is a challenging task in normal times and a priority in times of crisis. There is no 'onesize-fits-all' solution that addresses nutrition. In relevance to the COVID-19 (coronavirus disease 2019) pandemic crisis, viral infections in general and RNA viruses in particular are known to induce and promote oxidative stress, consequently increasing the body's demand for micronutrients, especially those related to antioxidant enzymic systems, thus draining the body of micronutrients, and so hindering the human body's ability to cope optimally with oxidative stress. Common polymorphisms in major antioxidant enzymes, with world population minor allele frequencies ranging from 0.5 to $50 \%$, are related to altered enzymic function, with substantial potential effects on the body's ability to cope with viral infection-induced oxidative stress. In this review we highlight common SNP of the major antioxidant enzymes relevant to nutritional components in the context of viral infections, namely: superoxide dismutases, glutathione peroxidases and catalase. We delineate functional polymorphisms in several human antioxidant enzymes that require, especially during a viral crisis, adequate and potentially additional nutritional support to cope with the pathological consequences of disease. Thus, in face of the COVID-19 pandemic, nutrition should be tightly monitored and possibly supplemented, with special attention to those carrying common polymorphisms in antioxidant enzymes.

\section{Key words: Nutrigenetics: Viral infections: Oxidative stress: Antioxidant enzymes}

(Received 12 May 2020; revised 13 September 2020; accepted 14 October 2020; accepted manuscript published online 21 October 2020)

\section{Introduction}

Tight interaction exists between nutrition and the immune system. The necessity of optimal nutrition for the function, efficiency and capability of the immune system to cope with external and internal insults is well known ${ }^{(1)}$. Consequently, poor nutrition states predispose the body to a compromised immune state ${ }^{(2,3)}$. Macro- and micronutrient deficiencies and suboptimal nutritional intakes are common worldwide in both developing and developed countries, and may adversely affect the individual's immune system. Furthermore, specific sub-populations are more vulnerable to nutritional deficiencies at different time points in the cycle of life (infants, adolescents, pregnant women, elderly) and in specific states (hospitalised patients, chronic diseases) ${ }^{(4)}$. Although undernutrition clearly predisposes to immune deficiencies, overnutrition and obesity have also been shown to alter immunocompetence ${ }^{(5)}$. In fact, obesity is characterised by chronic, low-grade inflammation, which significantly contributes to the pathogenesis of obesity co-morbidities and to increased susceptibility to various infections ${ }^{(6-8)}$. The interaction between the immune response and nutritional status is highlighted in the context of oxidative stress during viral infections. While redox balance is critical to life and highly dependent on nutritional factors, viruses trigger by different mechanisms pro-oxidative and unbalanced redox states, which both aggravate the host response and promote virus survival. In fact, viral infections are characterised by a spectrum of clinical phenomena, with oxidative stress being one of their hallmarks ${ }^{(9)}$.

One clear illustration of the strong link between nutrition and immunity in the context of viral infection is the case of Se. Se is an essential micronutrient that, through its incorporation into selenoproteins, takes part in the regulation of oxidative stress, redox balance and other crucial cellular processes, including the innate and adaptive immune response. Se has been shown to be involved in T-lymphocyte proliferation and in the humoral system $^{(4)}$. Se deficiency was found to enhance the virulence or progression of some RNA viral infections, while Se supplementation was shown to augment antiviral immunity against endemic coxsackievirus and to prevent viral genomic RNA adaptations that lead to increased virulence and cardiac pathology in Keshan disease ${ }^{(10)}$. Similarly, another RNA virus, influenza A, was shown to undergo increased mutational alterations in genomic RNA due to Se deficiency ${ }^{(11)}$. Among HIV-1-infected individuals, lower serum Se concentrations have been associated with lower $\mathrm{CD}_{4}{ }^{+}$T cell counts, greater HIV-1 disease progression and higher HIV-1-related mortality ${ }^{(12)}$. Interestingly, human subjects vaccinated against poliovirus antigens showed more rapid clearance of the poliovirus, with lower number of the poliovirus mutations and more robust Th1 immune

Abbreviations: CAT, catalase; GPx, glutathione peroxidase; HCV, hepatitis C virus; MAF, minor allele frequency; ROS, reactive oxygen species; SOD, superoxide dismutase.

Corresponding author: Professor Ruth Birk, email ruthb@ariel.ac.il 
responses, when supplemented with Se, as compared with human subjects with low Se status ${ }^{(13)}$. One of the human body's fundamental anti-oxidative systems is the antioxidant enzymes. Antioxidant enzymes need nutritional factors, mainly micronutrients, as co-activators for optimal function. Major antioxidant enzymes have common polymorphisms related to altered enzymic function with world population minor allele frequencies (MAF) ranging from 0.5 to $50 \%$, which could substantially affect the body's ability to cope with viral infection-induced oxidative stress. Thus, in light of the COVID-19 (coronavirus disease 2019) pandemic, there is a critical need to consider personalised nutritional needs related to one of the fundamental viral pathological mechanisms, oxidative stress.

Reactive oxygen species: antioxidant defence system and related nutritional needs

The redox balance, or the anti/pro-oxidative balance in human cells, is of utmost importance to survival. Reactive oxygen species (ROS), typically oxygen and NO radicals, are consistently produced in and by cells in normal physiological processes, serving an important role in cellular and physiological functions, such as cellular signalling, regulation of cytokines, growth factors, transcription, immunomodulation and apoptosis, as well as in other processes ${ }^{(14)}$. The cellular ROS levels are tightly maintained by complex intracellular regulatory systems. However, an unbalanced, uncontrolled pro-oxidative redox state results in damage to DNA, lipids and proteins, as well as loss of cellular integrity, and is linked to the initiation, development, progression and outcome of most human diseases, including infectious diseases. To keep cellular homeostasis and prevent a deleterious oxidative state, a sophisticated and synergistic antioxidant defence system, consisting of both enzymic and non-enzymic factors, is continuously activated. Non-enzymic antioxidants are mainly dietary components, classified generally as essential vitamins and minerals; and non-essential components, including phytochemicals - such as polyphenols, carotenoids and organosulfur compounds. The endogenous enzymic antioxidant system is comprised mainly of superoxide dismutase (SOD), catalase (CAT) and glutathione peroxidase (GPx) as well as other enzymes. The major antioxidant enzymes SOD1-3 catalyse the dismutation of superoxide $\left(\mathrm{O}_{2}^{-}\right)$oxidative radicals into $\mathrm{O}_{2}$ and $\mathrm{H}_{2} \mathrm{O}_{2}$. Followed by SOD activity, two other antioxidant enzymes, CAT, a tetrameric haemoprotein, and GPx, convert $\mathrm{H}_{2} \mathrm{O}_{2}$ to water and $\mathrm{O}_{2}$. The importance of these enzymes to human health is evident through numerous studies, demonstrating that abnormal SOD is linked to several diseases, including amyotrophic lateral sclerosis, Down's syndrome and carcinogenesis $^{(15,16)}$. Similarly, studies have shown the involvement of GPx in cancer, diabetes, angiogenesis, endothelial dysfunction, atherosclerosis, and cardiac dysfunction ${ }^{(17,18)}$. The majority of detoxification enzymes depend on dietary minerals as cofactors for optimal activity. For example, of the three human SOD isoforms, the cytosolic SOD1 uses $\mathrm{Cu}$ or $\mathrm{Zn}$ ions, the mitochondrial SOD2 uses Mn, the extracellular SOD3 also uses $\mathrm{Cu} / \mathrm{Zn}$, and GPx uses Se. Furthermore, as elimination of ROS is usually an orchestrated process, where the activity of one enzyme is followed by another, if the activity of one enzyme is not optimal and balanced by that of the following enzyme, the generation of ROS is accelerated.

Fruits and vegetables are a rich source of exogenic antioxidants, such as vitamins $\mathrm{C}$ and $\mathrm{E}$ and minerals ( $\mathrm{Mg}, \mathrm{Zn}, \mathrm{Mn}$ and Se) and also of non-essential phytochemicals (polyphenols and carotenoids). Numerous studies have shown that a diet rich in fruits and vegetables is associated with reduced risk of chronic diseases ${ }^{(19,20)}$. In fact, it has been shown that during oxidative stress, dietary components can modify total antioxidant capacity, an analyte frequently used to assess the antioxidant status of biological samples, improving redox status and consequently delaying or preventing progression and onset of diseases. Dietary total antioxidant capacity has been shown to be associated with risks of several chronic diseases, such as diabetes, hypertension and CVD, etc. ${ }^{(21-30)}$.

\section{Reactive oxygen species, viral infection and antioxidant enzymes}

In the context of viral infections, many human viruses, including HIV, herpes simplex virus type 1, hepatitis B virus, hepatitis C virus (HCV), respiratory syncytial virus, influenza viruses and SARS (severe acute respiratory syndrome) coronavirus, produce ROS by diverse mechanisms ${ }^{(31-35)}$. As SARS-CoV-2 virus has $80 \%$ homology to SARS coronavirus, it probably uses similar mechanisms ${ }^{(36)}$. In recent years, several reviews summarised the involvement of ROS in the pathogenesis of viral infections in general and in RNA viruses in particular ${ }^{(37-39)}$. Although not the focus of this review, in brief, during viral infections, one of the virus's infection strategy to promote viral pathogenesis is to modulate the intracellular redox state as a byproduct of survival efforts and as part of their replication mechanism. Ultimately, virus-induced host cells, as a mechanism of pathogen elimination and viral spread limitation ${ }^{(40)}$, secrete cytokines, which trigger host ROS production ${ }^{(39)}$. Host-triggered phagocytes activate the NADPH oxidase complex and NO synthase, resulting in simultaneous release of ROS and pro-oxidant cytokines, such as TNF and IL-1 ${ }^{(14)}$. In turn, TNF and IL-1 trigger a chain of cellular events, such as mitochondrial pro-oxidant activity and stimulation of neutrophils to release lysosomal proteins, including lactoferrin, which may result in an elevated production of ROS. As viral multiplication progresses, more ROS are formed, causing an imbalance in cellular redox homeostasis, thus contributing to the severity of the inflammatory responses, cell death, weight loss and other typical phenomena ${ }^{(37,38)}$. The cellular redox homeostasis imbalance can in turn further contribute to viral survival by selecting for certain viral mutants and activating transcription factors, such as NF- $\kappa \mathrm{B}$, which increases viral replication ${ }^{(39)}$.

In general, viruses, although varying in the production of ROS, share a common pathogenic pathway which results in host antioxidant system depletion ${ }^{(38)}$. For example, patients infected by hepatitis B virus show a reduction in $\mathrm{Cu} / \mathrm{Zn}-\mathrm{SOD}$ and GPx enzymes ${ }^{(39)}$; patients with dengue fever exhibit alteration in oxidative stress status as the disease progresses, with decrease in the glutathione and total antioxidant status following 
infection $^{(15)}$; and HIV patients show significantly reduced levels of GSH, cysteine, vitamin C, GPx and SOD in plasma and leucocytes, and an increase in levels of lipid peroxidation ${ }^{(17,41,42)}$.

The critical importance of both antioxidant enzymes and nutritional components to the course of viral infection is clearly demonstrated by numerous in vivo and in vitro studies (mostly in animals), highlighting the therapeutic potential but also the limitations of this therapy ${ }^{(43,44)}$. Some examples in a nutshell: injecting SOD conjugated with a pyran copolymer protected mice against a potentially lethal influenza virus infection ${ }^{(45)}$; the administration of recombinant human CAT to mice infected with H1N1 influenza A virus decreased inflammatory cell infiltration, inflammatory cytokine levels and the mRNA levels of the Toll-like receptors and NF- $\mathrm{KB}^{(46)}$. Moreover, it was demonstrated that oxidative stress positively affects viral RNA replication and that antioxidant treatment can significantly impair viral RNA replication, altering the amount of capped viral $\mathrm{RNA}^{(47)}$. Clinical studies have shown that the addition of antioxidants can decrease liver injury caused by oxidative stress, suggesting that this could be a potential treatment for HCV infection ${ }^{(48,49)}$. Studies have also shown that the administration of exogenous GSH inhibits dengue virus- 2 viral production by modulating $\mathrm{NF}-\kappa \mathrm{B}$ activity and reducing ROS production ${ }^{(50,51)}$. Vitamin and micronutrient supplementation has been shown to improve outcomes in HIV-infected patients either alone or with antiretroviral treatment ${ }^{(52,53)}$. Vitamin E supplementation decreased lung virus titres in mice infected with influenza ${ }^{(54,55)}$. SOD, CAT and GPx were significantly increased in rats after oral dosage of astaxanthin $^{(56)}$. A vitamin $\mathrm{C}$ supplement was demonstrated to have a beneficial effect in influenza infections, mainly in experimental models; however, this effect has not been reported in patients $^{(57)}$. Herpes zoster infection patients receiving intravenous vitamin $C$ supplement had a significant reduction in pain scale scores ${ }^{(58)}$. However, it should be noted that the role of antioxidants in viral infections is more complex than the mere antiviral host defence and viral survival strategies, as it includes many other effects related to metabolic regulation both of host and viral survival. Thus, viral infection simultaneously increases the demand for micronutrients and causes their loss, which leads to an antioxidant deficiency that should be monitored and addressed as an essential part of viral treatment. However, due to the complexity of the viral-host interaction, the complex effects of ROS-antioxidant interactions and the lack of clinical studies, well-designed clinical trials are required to study the use of antioxidants as a therapy in viral infections.

In the context of the present review, one of the overlooked areas which requires scientific and clinical attention is the existence of functional polymorphisms in genes encoding antioxidant enzymes, which alter the function of the enzymes, with possible implications on antioxidant nutritional requirements and treatment (Table 1).

\section{Superoxide dismutase polymorphisms and diseases}

The human SOD1 gene is located on chromosome 21q22, SOD2 on chromosome $6 \mathrm{q} 25^{(30,59)}$ and SOD3 on chromosome $4 \mathrm{q} 21^{(60,61)}$. Due to their essential role in conserving cellular integrity and redox balance, functional alterations in SOD1, SOD2 and SOD3 have been linked to common diseases, including inflammatory bowel disease ${ }^{(62,63)}$, obesity ${ }^{(64,65)}$, diabetes and hypertension ${ }^{(30,66-70)}$, chronic obstructive pulmonary disease $^{(71-75)}$ and $\mathrm{CVD}^{(59)}$, etc. Surprisingly, although polymorphisms in the antioxidant genes may determine cellular oxidative stress levels, with significant implications for the pathogenesis of viral infections and their complications, scarce research exists on this issue. Farawela et al. ${ }^{(76)}$ studied 100 Egyptian patients with B cell-non-Hodgkin lymphoma and 100 controls to test the association between HCV infection, oxidative stress gene polymorphisms and B cell-non-Hodgkin lymphoma risk. Concomitant HCV infection and GPX1 gene polymorphism (Pro ${ }^{197} \mathrm{Leu}$ ) had a synergetic effect on non-Hodgkin lymphoma risk with an OR of 15. SOD2 (Val16Ala) and CAT(C-262T) genetic polymorphisms were not found to confer increased non-Hodgkin lymphoma risk. Similarly, Ezzikouri et $a l^{(77)}$ found a significant association between homozygosity of the SOD2 (Val16Ala) variant polymorphism and hepatocellular carcinoma occurrence in HCV-infected Moroccan patients.

In humans, at least 111 SNP have been identified for SOD1 and 100 for SOD3; however, information regarding these polymorphisms in the context of chronic diseases is lacking ${ }^{(75-78)}$. Most of the SNP, summarised in a recent review, are not known to be functional, yet are located in non-coding intronic genetic regions with possible regulatory implications ${ }^{(75)}$. Of clinical significance is the functional SNP rs1799895 (worldwide MAF 0.5$10 \%$ ), which changes arginine to glycine at position 213 (R213G) at the SOD 3 carboxy-terminus, resulting in alteration of the positive charge of the terminus, and consequent release of SOD3 from the extracellular matrix to the extracellular fluids such as plasma and epithelial lining fluids ${ }^{(79)}$. SOD3 is highly expressed in arteries $^{(80)}$, lungs, airways ${ }^{(81)}$ and alveolar macrophages ${ }^{(82)}$. Studies in both human subjects and mice have shown that SOD3 plays a key role in decreasing lung injury by reducing oxidative stress ${ }^{(83)}$. In fact, SOD3 R213G carriers have reduced risk of exacerbations of chronic obstructive pulmonary disease ${ }^{(35)}$. In a recent elegant study, Gaurav et al. ${ }^{(79)}$ showed that knock-in mice analogous to the human SOD3 R213G SNP had lower airway hyper-responsiveness, inflammation and mucus hypersecretion with decreased IL-33 in bronchoalveolar lavage fluid and reduced type II innate lymphoid cells in the lungs. This study suggests the potential benefit of SOD3 R213G SNP carriers, as they highly express SOD3 in the airway-lining fluid, thus ameliorating allergic airway inflammation by diminishing the innate immune response, including IL-33-mediated changes in innate lymphoid cells ${ }^{(79)}$. Of note, the SOD3 R213G SNP was also reported to increase the risk of IHD in The Copenhagen City Heart Study ${ }^{(84)}$.

The nuclear SOD2 gene is translated in the cytoplasm with a mitochondrial targeting sequence; the enzyme is then transported into the mitochondria, processed, and assembled into an active homo-tetramer ${ }^{(59)}$. SOD2 is present in the mitochondria, the major ROS production organelle in aerobes, thus playing a pivotal role in health and disease ${ }^{(78)}$. In humans, at least 190 SNP have been identified for SOD2(30,59) . The most studied SOD2 functional SNP is Ala16Val (rs4880) in exon 2, which causes a conformational change in the mitochondrial targeting domain, 
Table 1. Summary of oxidative enzyme polymorphism and nutrition interactions

\begin{tabular}{|c|c|c|c|c|}
\hline Gene & Polymorphism & $\begin{array}{l}\text { Minor allele } \\
\text { frequency }\end{array}$ & Nutrition interaction & Reference \\
\hline \multirow[t]{9}{*}{ SOD2 } & \multirow[t]{9}{*}{ Val16Ala } & \multirow{9}{*}{$\begin{array}{c}11.7 \% \text { East } \\
\text { Asian, } 50 \% \\
\text { European, } \\
62 \% \text { Latin } \\
\text { American }\end{array}$} & $\begin{array}{l}\text { Alcoholic cirrhosis patients that have at least one Ala16Val allele are at increased risk for hepatocellular carcinoma occurrence } \\
\text { and death }\end{array}$ & $\begin{array}{l}(93) \\
(94-97)\end{array}$ \\
\hline & & & \multirow{3}{*}{ 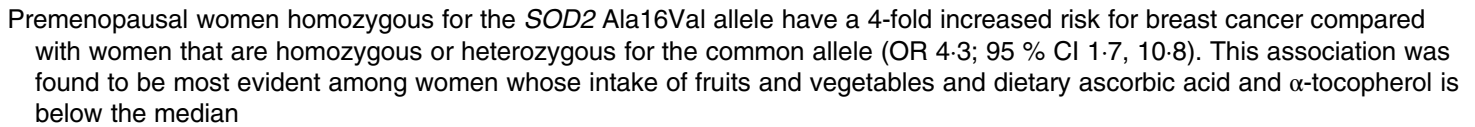 } & (98) \\
\hline & & & & (99) \\
\hline & & & & $\begin{array}{l}(100) \\
(101,102)\end{array}$ \\
\hline & & & $\begin{array}{l}\text { Men homozygous for the variant allele had a } 70 \% \text { increased risk for prostate cancer compared with men homozygous for the } \\
\text { wild-type allele (OR } 1.72 ; 95 \% \mathrm{Cl} 0.96,3.08) \text {. Supplementation with } \alpha \text {-tocopherol had no impact on the SOD2-prostate } \\
\text { cancer association }\end{array}$ & (103) \\
\hline & & & $\begin{array}{l}\text { Significant interaction between prostate cancer risk, } S O D 2 \text { homozygous variant genotype and low baseline plasma antioxidant } \\
\text { levels, where homozygote genotype and low antioxidant levels incurred almost } 4 \text {-fold increased risk of prostate cancer. Men } \\
\text { homozygous for the variant allele genotype had a } 10 \text {-fold increased risk for aggressive prostate cancer across quartiles of } \\
\text { antioxidant status }\end{array}$ & \\
\hline & & & $\begin{array}{l}\text { Reduced risk of cervical carcinogenesis subtype was associated with the variant allele only among those with above median } \\
\text { levels of serum } \beta \text {-carotene and } \gamma \text {-tocopherol }\end{array}$ & \\
\hline & & & $\begin{array}{l}\text { Women carriers of at least one SOD2 variant allele who had a high vegetable intake have lowered breast cancer risk by } \\
\text { almost half compared with those with a low vegetable intake }\end{array}$ & \\
\hline & & & $\begin{array}{l}\text { Greek-Cypriot women carriers of at least one SOD2 variant allele, with high vegetable intake, have lowered breast cancer risk } \\
\text { by almost half compared with women with low vegetable intake }\end{array}$ & \\
\hline \multirow[t]{5}{*}{ CAT } & \multirow[t]{3}{*}{$\begin{array}{l}\text { C-262T } \\
\quad(\text { rs1001179) }\end{array}$} & \multirow[t]{3}{*}{$8-26 \%$} & $\begin{array}{l}\text { Women homozygous for the common } \mathrm{C} \text { allele who consumed high-fruit diet showed a significantly lower risk for breast cancer } \\
(\text { OR } 0.59 ; 95 \% \mathrm{Cl}, 0.38,0.89)\end{array}$ & $\begin{array}{l}(116) \\
(103)\end{array}$ \\
\hline & & & $\begin{array}{l}\text { Women with at least one CAT -262C allele and high vegetable intake had lower breast cancer risk (OR high } v \text {. low for - } \\
262 \mathrm{CC}=0.66,95 \% \mathrm{Cl} 0.47,0.92 \text {; for }-262 \mathrm{CT}=0.53,95 \% \mathrm{Cl} 0.35,0.81)^{(83)}\end{array}$ & $\begin{array}{l}(116) \\
(118)\end{array}$ \\
\hline & & & $\begin{array}{l}\text { Women with low vegetable and fruit intake (< median), the low-risk CATCC (OR } 1.33 ; 95 \% \mathrm{Cl}=0.89,1.99) \text { genotype } \\
\text { appeared to be associated with higher breast cancer risk, with significantly increased risks observed in those with } \geq 4 \text { low- } \\
\left.\text { risk alleles compared with participants with } \leq 2 \text { low-risk alleles (OR } 1.77 ; 95 \% \mathrm{Cl} 1.05,2.99 ; P_{\text {interaction }} 0.006\right) \\
\text { Inter-individual variation in antioxidant genes, including the CAT rs12807961 SNP, could interact with dietary intake to } \\
\text { influence pancreatic cancer risk }\end{array}$ & \\
\hline & $\begin{array}{l}\text { A-21T } \\
(\text { rs7943316) }\end{array}$ & $25-48 \%$ & $\begin{array}{l}\text { The frequencies of both allele }-21 \mathrm{~A} \text { and }-21 \mathrm{AA} C A T \text { genotypes were higher among asthmatics than among healthy controls } \\
\text { Low fruit and vegetable consumers (once per d or less) possessing the } C A T-21 \mathrm{AA} \text { genotype were at increased risk of both } \\
\text { allergic and non-allergic asthma }\end{array}$ & (109) \\
\hline & (rs12807961) & $25-33 \%$ & $\begin{array}{l}\text { Inter-individual variation in antioxidant genes, including the CAT rs12807961 SNP, could interact with dietary intake to } \\
\text { influence pancreatic cancer risk }\end{array}$ & (118) \\
\hline \multirow[t]{4}{*}{ GPx1 } & \multirow[t]{4}{*}{$\begin{array}{l}\text { Pro }^{198} \text { Leu } \\
\quad(\text { rs1050450) }\end{array}$} & \multirow[t]{4}{*}{$28 \%$} & $\begin{array}{l}\text { GPX1 Pro }{ }^{198} \text { Leu variant allele results in lesser response to the stimulation of GPx1 enzyme activity during Se supplementation } \\
\text { compared with the common allele }\end{array}$ & $\begin{array}{c}(130) \\
(133-135)\end{array}$ \\
\hline & & & GPx1 Pro ${ }^{198}$ Leu genotypes differentially affected the Se status and GPx activity & (137) \\
\hline & & & Brazil nut supplementation significantly increased GPx1 mRNA expression only in subjects with the CC genotype ${ }^{(117)}$ & (141) \\
\hline & & & $\begin{array}{l}\text { Homozygotes for the variant allele had higher colorectal cancer risk with alcohol consumption and homozygotes for the } \\
\text { common allele with higher dietary vitamin } \mathrm{C} \text { intake had reduced risk of colorectal cancer }{ }^{(120)}\end{array}$ & \\
\hline \multirow[t]{2}{*}{ GPx4 } & \multirow[t]{2}{*}{$\begin{array}{l}718 \mathrm{~T} / \mathrm{C} \\
\quad(\mathrm{rs} 713041)\end{array}$} & \multirow[t]{2}{*}{$35-44 \%$} & $\begin{array}{l}\text { Elevated adhesion levels in HUVEC and monocytes in individuals homozygous for the T-variant compared with carriers of the } \\
\text { C-variant. This effect was modified by Se and PUFA }{ }^{(139)}\end{array}$ & $\begin{array}{l}(139) \\
(140)\end{array}$ \\
\hline & & & $\begin{array}{l}\text { Se supplementation for } 6 \text { weeks in non-smokers, both lymphocyte GPx1 protein concentrations and plasma GPx3 activity } \\
\text { increased significantly in individuals homozygous CC in the GPx4 718 T/C (rs713041) SNP but not in homozygote TT } \\
\text { participants. After Se withdrawal, there was a significant fall in both lymphocyte GPx4 protein concentration and activity in } \\
\text { the homozygote TT, but not in homozygote CC participants }\end{array}$ & \\
\hline
\end{tabular}

$S O D 2$, superoxide dismutase 2; CAT, catalase; GPx, glutathione peroxidase; HUVEC, human umbilical vein endothelial cells. 
from $\alpha$-helix to $\beta$-sheet secondary structure, consequently affecting $S O D 2$ activity in the mitochondria ${ }^{(30)}$. Numerous studies have shown that the SOD2 Ala16Val SNP is significantly associated with altered progression and risk of different diseases, such as diabetes and diabetes co-morbidities ${ }^{(59,85-87)}$, epilepsy ${ }^{(88)}$, cancer $^{(89)}$, pre-eclampsia ${ }^{(90)}$ and $\mathrm{CVD}^{(59,78,91)}$, etc. The SOD2 Ala16Val (rs4880) mean allelic frequency is highly variable in different populations, ranging from $11.7 \%$ in the East Asian population, to $50 \%$ in European cohorts, to $62 \%$ in Latin American population $\left(\operatorname{BLAST}^{(92)}\right)$.

\section{Superoxide dismutase $2 \mathrm{Ala} 16 \mathrm{Val}$ SNP and dietary factors}

Several known disease risk factors have been shown to interact with the SOD2 Ala16Val polymorphism, including smoking and alcohol consumption. Alcohol promotes the generation of ROS through numerous processes, particularly in the liver, the main organ that metabolises and detoxifies alcohol. Nahon et al. ${ }^{(93)}$ reported that alcoholic cirrhosis patients who have at least one Ala16Val allele are at increased risk for hepatocellular carcinoma occurrence and death.

Conflicting evidence exists regarding the interaction between the SOD2 Ala16Val polymorphism and dietary components. Women homozygous for the SOD2 Ala16Val variant allele have a 4-fold increased risk for breast cancer compared with women who are homozygous or heterozygous for the common allele (OR 4.3; $95 \%$ CI $1.7,10 \cdot 8$ ); this effect is particularly evident in premenopausal women. This association was found to be most evident among women whose intake of fruits and vegetables and dietary ascorbic acid and $\alpha$-tocopherol is below the median $^{(94-97)}$. The Alpha-Tocopherol, Beta-Carotene Cancer Prevention Study found that men homozygous for the variant allele had a $70 \%$ increased risk for prostate cancer compared with men homozygous for the wild-type allele (OR 1.72; $95 \%$ CI $0.96,3.08)^{(98)}$. However, supplementation with $\alpha$-tocopherol had no impact on the SOD2-prostate cancer association. The Physicians' Health Study found significant interaction between prostate cancer risk, SOD2 homozygous variant genotype and low baseline plasma antioxidant levels, where homozygote genotype and low antioxidant levels incurred almost 4-fold increased risk of prostate cancer. Men homozygous for the variant allele genotype had a 10-fold increased risk for aggressive prostate cancer across quartiles of antioxidant status ${ }^{(99)}$.

Tong et al. ${ }^{(100)}$ studied the interaction between SOD2 genotypes and cervical carcinogenesis risk and the modulating effects of serum antioxidant nutrient status ( $\beta$-carotene, lycopene, zeaxanthin/lutein, retinol, $\alpha$-tocopherol and $\gamma$-tocopherol). They found that the reduced risk of cervical carcinogenesis subtype was associated with the variant allele only among those with above median levels of serum $\beta$-carotene and $\gamma$-tocopherol. Two meta-analyses have examined the association between the SOD2 Val16Ala polymorphism, breast cancer risk and vitamin C, vitamin E and carotenoid ${ }^{(82)}$ and fruit and vegetable consumption $^{(101)}$. Their results suggest that the SOD2 Val16Ala polymorphism may contribute to cancer development through a disturbed antioxidant balance; while both meta-analyses showed no independent effect of genotype on breast cancer risk, intakes of antioxidants were shown to modify risk in premenopausal women ${ }^{(101)}$, while fruit and vegetable consumption did not $^{(102)}$. Similarly, Kakkoura et al. $^{(103)}$ showed that in GreekCypriot women who were carriers of at least one SOD2 variant allele, high vegetable intake lowered breast cancer risk by almost half compared with low vegetable intake. Taken together, despite inconsistencies, the overall results suggest that the SOD2 Ala16Val SNP can be modulated by dietary factors. However, further studies are needed to establish the nature of this association ${ }^{(30,59)}$.

\section{Catalase polymorphisms and dietary factors}

The CAT gene, mapped to chromosome 11p13, encodes a tetrameric haemoprotein expressed in all aerobes; the highest levels of the enzyme are found in the liver, kidney and erythrocytes. Numerous $C A T$ polymorphisms have been described in the promoter, $5^{\prime}$ and $3^{\prime}$ - untranslated regions, exons and introns ${ }^{(104,105)}$. Significant associations were found between CAT polymorphisms and the risk of various diseases, including diabetes ${ }^{(106,107)}$, hypertension $^{(108)}$, asthma $^{(109,110)}$, breast cancer ${ }^{(111)}$ and others. However, results of the various studies are inconsistent, explained at least in part by different populations, methodologies and disease course.

Of the CAT SNP presented in the National Center for Biotechnology Information (NCBI) database, the most studied in relation to human diseases is CAT C-262T (rs1001179), with mean world population frequency ranging from 8 to $26 \%$. The common CAT C262T polymorphism is located in the gene promoter region and its correlation with CAT activity is controversial $^{(111-113)}$. However, the CAT C262T polymorphism was linked to host response to oxidative stress ${ }^{(111)}$. Indeed, variant CAT T alleles have been associated with increased risk for conditions related to oxidative stress, such as hypertension ${ }^{(114)}$ and vitiligo $^{(115)}$. Ahn et al. ${ }^{(116)}$ (Long Island Breast Cancer Study Project) have shown that women homozygous for the common $\mathrm{C}$ allele had a $17 \%$ reduction in risk of breast cancer compared with those with at least one variant $\mathrm{T}$ allele. Women homozygous for the common $\mathrm{C}$ allele who consumed a high-fruit diet showed a significantly lower risk for breast cancer (OR 0.59; $95 \%$ CI 0.38, 0.89). In a follow-up study, Ahn et al. ${ }^{(116)}$ found that differences in CAT activity by genotype were most pronounced among those in the highest tertiles of fruit and vegetable consumption. Similarly, Kakkoura et al. ${ }^{(103)}$ found that high vegetable intake lowered breast cancer risk in Greek-Cypriot women with at least one CAT $-262 \mathrm{C}$ allele (OR high $v$. low for $-262 \mathrm{CC}=0 \cdot 66,95 \% \mathrm{CI}$ $0 \cdot 47,0.92$; for $-262 \mathrm{CT}=0.53,95 \%$ CI $0 \cdot 35,0 \cdot 81$ ). Analysing the Cancer Prevention Study-II Nutrition Cohort, Li et al. ${ }^{(117)}$ studied the interaction of a combined haplotype of SNP of common antioxidant enzymes with the level of vegetable and fruit intake on breast cancer risk in postmenopausal women. They found joint effects of endogenous and exogenous antioxidants, where among women with low vegetable and fruit intake ( $<$ median), the low-risk CAT CC (OR 1.33; $95 \%$ CI 0.89, 1.99) genotype appeared to be associated with higher breast cancer risk, with significantly increased risks observed in those with $\geq 4$ low-risk alleles compared with participants with $\leq 2$ low-risk alleles 
$\left(\text { OR } 1.77 ; 95 \% \text { CI 1.05, 2.99; } P_{\text {interaction }}=0.006\right)^{(116)}$. Similarly, Jansen et $a l{ }^{(118)}$ found that inter-individual variation in antioxidant genes, including the CAT rs12807961 SNP, could interact with dietary intake to influence pancreatic cancer risk.

Another CAT SNP in the gene promoter region (rs7943316, worldwide MAF 25-48 \%), an A>T substitution at position -21 (A-21T), has been studied in relation to interaction with nutritional factors. Polonikov et al. ${ }^{(109)}$ found that the frequencies of both allele -21A and -21AA CAT genotypes were higher among asthmatics than among healthy controls. Notably, no association of CAT genotype -21AA with asthma was found in high fruit and vegetable consumers, whereas low fruit and vegetable consumers (once per $\mathrm{d}$ or less) possessing this genotype were at increased risk of both allergic and non-allergic asthma.

Taken together, there is growing evidence pointing to a possible interaction between $C A T$ polymorphisms and relevant nutrients, indicating that an individual's genome should be taken into consideration when planning nutrient intake and that interaction between dietary components and the personal genome is a significant factor in health and disease.

\section{Catalase polymorphisms and viral infection}

Most of the quite limited publications regarding CAT polymorphisms and viral infection are related to either HCV and hepatic carcinoma or to HIV, with only initial and conflicting findings, warranting much needed future studies ${ }^{(76,119,120)}$. SNP have been associated with airway diseases, including asthma and chronic obstructive pulmonary disease ${ }^{(121)}$; however, little is known in this context regarding virus-induced lung disorders. Chambliss et $a l^{(122)}$ have shown that respiratory syncytial virus infection is associated with oxidative lung injury, decreased levels of antioxidant enzymes and degradation of the transcription factor NFE2-related factor 2, a master regulator of antioxidant enzyme expression. Additionally, Chambliss et al. ${ }^{(122)}$ demonstrated that the $C A T$ rs1001179 $(-262 \mathrm{C} / \mathrm{T})$ polymorphism in the lung may play an important and protective role in respiratory syncytial virus-associated lower respiratory tract infections in children heterozygous or homozygous for the variant allele. Similarly, the presence of the $C A T$ rs1001179 (-262C/T) T allele has been previously associated with a decreased risk of asthma in nonsmokers in the Hong Kong Chinese population ${ }^{(123)}$, yet with an increased risk of new-onset of asthma among Hispanic and Caucasian children ${ }^{(124)}$. To the best of our knowledge, no research has been conducted on the interaction between CAT polymorphism, viral infection and nutrition. Due to the important and proven interaction between CAT and nutritional factors, future such studies are needed.

\section{Glutathione peroxidases}

The glutathione peroxidases (GPx) are a family of Se-dependent enzymes encoded by discrete genes located on different chromosomes. The human genome harbours twenty-five selenoprotein genes, of which eight GPx paralogues have been identified, namely GPx1 (locus 3p21.3), GPx2 (locus 14q24.1), GPx3 (locus 5q23), GPx4 (locus 19p13.3), GPx5 (locus 6p22.1), GPx6 (locus 6p22.1), GPx7 (locus 1p32) and GPx8 (locus 5q11.2) ${ }^{(125)}$. Five of these eight GPx paralogues contain a selenocysteine residue in the catalytic site (GPx1-GPx4, GPx6) and three have a cysteine instead (GPx5, GPx7 and GPx8) ${ }^{(9)}$. GPx1 and GPx4 are ubiquitously expressed; GPx1 (mostly abundant in erythrocytes, kidney and liver) is cytoplasmic, while GPx4 is localised to the cytoplasmic, mitochondrial and nuclear cellular compartments. GPx2 is present in epithelial tissues including the gastrointestinal tract, lung, skin and liver. GPx3 is secreted to the plasma and excreted mostly by the kidney. GPx6 is only found in the olfactory epithelium and embryonic tissues. The enzymic activity of GPx is directly proportional to Se intake; therefore, there is a strong link between Se deficiency and oxidative stress. Consequently, several GPX SNP have been shown to have significant association with both Se status biomarkers and health outcome $^{(126)}$. For example, the $\mathrm{T}$ allele for GPx1 SNP rs1050450 has been shown to have a significant impact on high-grade prostate cancer risk, over a range of plasma/serum Se concentrations ${ }^{(127,128)}$. Many SNP have been identified in human GPx isoforms: 46 in GPx1, 73 in GPx2, 120 in GPx3, 88 in GPx4 and 93 in GPx $5^{(78)}$. However, functional consequences have been demonstrated in in vitro and in vivo studies in only a small number of those SNP in genes encoding selenoproteins ${ }^{(129)}$. GPx1 has four functional SNP, of which Pro ${ }^{197}$ Leu (rs1050450; worldwide MAF 22-35\%) has been studied most extensively in association with many diseases, including cancer $^{(78,116,130)}$, diabetes ${ }^{(131,132)}$, kidney diseases and vascular diseases ${ }^{(78,129)}$. However, studies assessing the association between the GPx1 Pro ${ }^{197}$ Leu SNP genotypes and diabetes, stroke, brain tumours and prostate cancer are currently inconclusive.

Regarding functional consequences of SNP of the other GPX in relation to human diseases, there is at present very little conclusive data: GPx1 rs1800668 was studied in the context of cancer and was found to be associated with an increased risk of oesophageal cancer; three functional SNP of the GPx2 isoform, three of GPx3 and six of GPx3 coding regions have been scarcely studied in relation to disease ${ }^{(78)}$.

\section{Glutathione peroxidase polymorphisms and dietary factors}

Evidently, the most studied nutrient in regard to GPx in general and GPx polymorphisms in particular is Se. Several SNP in selenoprotein-coding genes have been shown to be functionally significant and to affect the response of biomarkers of Se status to Se supplementation ${ }^{(133-135)}$. In particular, rs1050450 in GPx1, rs713041 in GPx4 and rs7579 in the selenoprotein-P gene are known to affect the expression of the respective selenoproteins. Of those, the GPx1 Pro ${ }^{198} \mathrm{Leu}$ (rs1050450) SNP is the most studied. This polymorphism has been shown to affect GPx activity in some, although not all studies ${ }^{(104)}$. Carriers of the variant allele have been shown to have significantly higher levels of lipid pre-oxidation components ${ }^{(136)}$. This polymorphism has also been associated with several types of cancer, with conflicting results reported. A pilot study by Cardoso et al. ${ }^{(137)}$ examined the effects of GPx1 Pro ${ }^{198} \mathrm{Leu}$ in response to Se supplementation 
via dietary Brazil nuts. GPx1 Pro ${ }^{198}$ Leu genotypes differentially affected the Se status and GPx activity. Similarly, a later study by Donadio et al. ${ }^{(138)}$ showed that Brazil nut supplementation significantly increased GPx1 mRNA expression only in subjects with the CC genotype. Crosley et $a l^{(139)}$ have demonstrated elevated adhesion levels in human umbilical vein endothelial cells (HUVEC) and monocytes in individuals homozygous for the T-variant of functional GPx4 (c718t) as compared with carriers of the $\mathrm{C}$-variant. This effect was modified by Se and PUFA. Méplan et al. ${ }^{(140)}$ showed that following clinical intervention with Se supplementation for 6 weeks in non-smokers, both lymphocyte GPx1 protein concentrations and plasma GPx3 activity increased significantly in homozygote CC individuals in the GPX4718 T/C (rs713041) SNP but not in homozygote TT participants. After Se withdrawal, there was a significant fall in both lymphocyte GPx4 protein concentration and activity in the homozygote TT, but not in homozygote CC participants ${ }^{(140)}$

Several studies, although scarce, show suggestive interaction between GPX1 polymorphisms and other dietary components: $\mathrm{Hu} \&$ Diamond ${ }^{(130)}$ have shown that the GPx1 Pro $^{198}$ Leu variant allele results in lesser response to the stimulation of GPx1 enzyme activity during Se supplementation compared with the common allele. Significant gene-diet interactions were found in the prospective Diet, Cancer and Health Study, where homozygotes for the variant allele had higher colorectal cancer risk with alcohol consumption and homozygotes for the common allele with higher dietary vitamin $\mathrm{C}$ intake had reduced risk of colorectal cancer ${ }^{(141)}$.

In summary, most of the published data regarding GPX polymorphisms and dietary components are related to Se, both in cancer and in viral infection. Although scarce data exist regarding other nutritional factors, it is quite clear from the publications so far that GPx are affected by dietary components, especially by Se, and that GPx polymorphisms can alter the need for dietary components and vice versa. This is particularly relevant to cancer and to viral infections.

\section{Glutathione peroxidase 1 polymorphisms and viral infection}

Se deficiency, which is a major regulator of selenoprotein expression, has been associated with the pathogenicity of several viruses. Moreover, several selenoprotein family members, including GPx, suggestively have an important role in different models of viral replication ${ }^{(9)}$. For instance, in Epstein-Barr virus infection, GPx activity reduction is associated with elevation in viral load $^{(142)}$. Supplementing herpes simplex virus-2 patients with selenium aspartate and multi-supplementation results in faster recovery, reduction in viral load and elevation in antiviral cytokines $^{(143)}$. The effect of GPx on inhibiting HIV activation is well documented. Correspondingly, Se can alter mutagenesis rates, both in viral genomes and in the DNA of mammalian cells exposed to carcinogens ${ }^{(9)}$. Similar to $C A T$, most published literature regarding GPX1 polymorphisms and viral infection is regarding chronic hepatitis C. Sousa et al. ${ }^{(119)}$ found that homozygosity to the common GPX1 Pro ${ }^{198} \mathrm{Leu}$ (rs1050450) allele was significantly associated with severity of liver fibrosis and chronic hepatitis C. Thus, they concluded that GPX1 polymorphisms may be implicated in the severity of liver fibrosis and HCC caused by $\mathrm{HCV}^{(118)}$. Farawela et al. ${ }^{(76)}$ found that HCV infection and GPX1 gene polymorphisms had a synergetic effect on non-Hodgkin lymphoma risk (OR 15; 95 \% CI 2.2, 69.6; $P<0 \cdot 0001$ ) in Egyptians.

\section{Conclusion and future directions}

Antioxidant enzymes have common functional polymorphisms, with world population MAF ranging from 0.5 to $50 \%$. These polymorphisms result in altered enzymic function, requiring scientific and clinical attention to whether the intake of specific micronutrients, that serve as cofactors of antioxidant enzymes, should be adjusted to enable carriers of the polymorphisms to better cope with oxidative stress. One of the major hallmarks of viral infections is oxidative stress, which contributes significantly both to the host pathophysiology and to viral function and replication. In relevance both to cancer and to viral infections, including the COVID-19 pandemic, good nutritional status should be monitored and implemented to reduce disease risk and to better cope with health challenges. In fact, many studies have shown that viral infection simultaneously increases the demand for micronutrients and causes their loss, which leads to antioxidant deficiencies that should be monitored and addressed as an essential part of treatment of viral infections in the general population and with special attention in individuals carrying functional polymorphisms in relevant genes.

Intriguing studies show a significant world prevalence of functional polymorphisms in antioxidant enzymes, with initial studies demonstrating gene-nutrient interactions (between antioxidant enzymes and micronutrient cofactors); these findings warrant special attention in future scientific and clinical studies to interactions of genetic polymorphisms in antioxidant enzymes with nutritional factors. Thus, future clinical and scientific studies should give special attention to the incorporation of subpopulations with common functional polymorphisms of antioxidant enzymes, in order to understand and possibly implement personalised nutrition in the future. Indeed, further studies (especially randomised controlled trials) are needed to unravel the optimal requirements of dietary micronutrients during viral infections in sub-populations with common functional polymorphisms of antioxidant enzymes. Such trials, beyond assessing the therapeutic benefits to different sub-groups, are needed to assess the secondary effects and to analyse whether these effects vary for different viral infections. Furthermore, analysing the antioxidant enzymes' functional genetic polymorphisms in in vitro and in vivo models could serve as a tool for both elucidating the much needed mechanism related to genetic backgroundnutrient interactions and serve as an experimental model for the study of developing 'cell-based' anti-viral nutritional agents.

\section{Acknowledgements}

The present review received no specific grant from any funding agency, commercial or not-for-profit sectors.

There are no conflicts of interest. 


\section{References}

1. Maggini S, Pierre A \& Calder PC (2018) Immune function and micronutrient requirements change over the life course. Nutrients 10, 1531.

2. Beck MA, Nelson HK, Shi Q, et al. (2001) Selenium deficiency increases the pathology of an influenza virus infection. FASEB J 15, 1481-1483.

3. Beck MA \& Matthews CC (2000) Micronutrients and host resistance to viral infection. Proc Nutr Soc 59, 581-585.

4. Saeed F, Nadeem M, Ahmed RS, et al. (2016) Studying the impact of nutritional immunology underlying the modulation of immune responses by nutritional compounds - a review. Food Agri Immun 27, 205-229.

5. Linus Pauling Institute Micronutrient Information Center (2016) Immunity in depth. http://lpi.oregonstate.edu/mic/ health-disease/immunity (accessed April 2020).

6. de Heredia FP, Gomez-Martinez S \& Marcos A (2012) Obesity, inflammation and the immune system. Proc Nutr Soc 71, 332-338.

7. Exley MA, Hand L, O'Shea D, et al. (2014) Interplay between the immune system and adipose tissue in obesity. JEndocrinol 223, R41-R48.

8. Mraz M \& Haluzik M (2014) The role of adipose tissue immune cells in obesity and low-grade inflammation. J Endocrinol 222, R113-R127.

9. Guillin OM, Vindry C, Ohlmann T, et al. (2019) Selenium, selenoproteins and viral infection. Nutrients 11, 2101.

10. Hoffmann PR \& Berry MJ (2008) The influence of selenium on immune responses. Mol Nutr Food Res 52, 1273-1280.

11. Nelson H, Shi KQ, Van Dael P, et al. (2001) Host nutritional selenium status as a driving force for influenza virus mutations. FASEB J 15, 1846-1848.

12. Look MP, Rockstroh JK, Rao GS, et al. (1997) Serum selenium versus lymphocyte subsets and markers of disease progression and inflammatory response in human immunodeficiency virus-1 infection. Biol Trace Elem Res 56, 31-41.

13. Broome CS, McArdle F, Kyle JA, et al. (2004) An increase in selenium intake improves immune function and poliovirus handling in adults with marginal selenium status. Am J Clin Nutr 80, 154-162.

14. Camini FC, da Silva Caetano CC, Almeida LT, et al. (2017) Implications of oxidative stress on viral pathogenesis. Arch Virol 162, 907-917.

15. Klassen P, Biesalski HK, Mazariegos M, et al. (2004) Classic dengue fever affects levels of circulating antioxidants. Nutrition 20, 542-547.

16. Powers KM, Oberley LW \& Domann FE (2008) The adventures of superoxide dismutase in health and disease: superoxide in the balance. In Oxidants in Biology, pp. 183-201 [G Valacchi and PA Davis, editors]. Dordrecht: Springer.

17. Malvy DJM, Richard MJ, Arnaud J, et al. (1994) Relationship of plasma malondialdehyde, vitamin $\mathrm{E}$ and antioxidant micronutrients to human immunodeficiency virus-1 seropositivity. Clin Chim Acta 224, 89-94

18. Lubos E, Loscalzo J \& Handy DE (2011) Glutathione peroxidase-1 in health and disease: from molecular mechanisms to therapeutic opportunities. Antioxid Redox Signal 15, 1957-1997.

19. Griffiths K, Aggarwal BB, Singh RB, et al. (2016) Food antioxidants and their anti-inflammatory properties: a potential role in cardiovascular diseases and cancer prevention. Diseases 4, 28.

20. López-Jaramillo P, Otero J, Camacho PA, et al. (2018) Reevaluating nutrition as a risk factor for cardio-metabolic diseases. Colomb Med (Cali) 49, 175-181.
21. Ghiselli A, Serafini M, Natella F, et al. (2000) Total antioxidant capacity as a tool to assess redox status: critical view and experimental data. Free Radic Biol Med 29, 1106-1114.

22. Wang Y, Yang M, Lee SG, et al. (2012) Dietary total antioxidant capacity is associated with diet and plasma antioxidant status in healthy young adults. J Acad Nutr Diet 112, $1626-1635$.

23. Villaverde P, Lajous M, MacDonald CJ, et al. (2019) High dietary total antioxidant capacity is associated with a reduced risk of hypertension in French women. Nutr J 18, 31.

24. Serafini M, Jakszyn P, Luján-Barroso L, et al. (2012) Dietary total antioxidant capacity and gastric cancer risk in the European Prospective Investigation into Cancer and Nutrition study. Int J Cancer 131, E544-E554.

25. Vece MM, Agnoli C, Grioni S, et al. (2015) Dietary total antioxidant capacity and colorectal cancer in the Italian EPIC cohort. PLOS ONE 10, e0142995.

26. Rossi M, Praud D, Monzio Compagnoni M, et al. (2014) Dietary non-enzymatic antioxidant capacity and the risk of myocardial infarction: a case-control study in Italy. Nutr Metab Cardiovasc Dis 24, 1246-1251.

27. Colarusso L, Serafini M, Lagerros YT, et al. (2017) Dietary antioxidant capacity and risk for stroke in a prospective cohort study of Swedish men and women. Nutrition 33, 234-239.

28. Mancini FR, Affret A, Dow C, et al. (2018) Dietary antioxidant capacity and risk of type 2 diabetes in the large prospective E3N-EPIC cohort. Diabetologia 61, 308-316.

29. Bastide N, Dartois L, Dyevre V, et al. (2017) Dietary antioxidant capacity and all-cause and cause-specific mortality in the E3N/EPIC cohort study. Eur J Nutr 56, 1233-1243.

30. Pourvali K, Abbasi M \& Mottaghi A (2016) Role of superoxide dismutase 2 gene Ala16Val polymorphism and total antioxidant capacity in diabetes and its complications. Avicenna J Med Biotechnol 8, 48-56.

31. Molteni CG, Principi N \& Esposito S (2014) Reactive oxygen and nitrogen species during viral infections. Free Radic Res 48, 1163-1169.

32. Burdon RH (1995) Superoxide and hydrogen peroxide in relation to mammalian cell proliferation. Free Radic Biol Med 18, 775-794.

33. Castro SM, Guerrero-Plata A, Suarez-Real G, et al. (2006) Antioxidant treatment ameliorates respiratory syncytial virus-induced disease and lung inflammation. Am J Respir Crit Care Med 174, 1361-1369.

34. Garofalo RP, Kolli D \& Casola A (2013) Respiratory syncytial virus infection: mechanisms of redox control and novel therapeutic opportunities. Antioxid Redox Signal 18, 186-217.

35. Li SW, Wang CY, Jou YJ, et al. (2016) SARS coronavirus papain-like protease induces Egr-1-dependent up-regulation of TGF- $\beta 1$ via ROS/p38 MAPK/STAT3 pathway. Sci Rep $\mathbf{6}$, 25754 .

36. Koyama T, Platt D \& Parida L (2020) Variant analysis of SARSCoV-2 genomes. Bull World Health Organ 98, 495-504.

37. Reshi ML, Su YC \& Hong JR (2014) RNA viruses: ROS-mediated cell death. Int J Cell Biol 2014, 467452.

38. Schwarz KB (1996) Oxidative stress during viral infection: a review. Free Radic Biol Med 21, 641-649.

39. Ha HL, Shin HJ, Feitelson M, et al. (2010) Oxidative stress and antioxidants in hepatic pathogenesis. World J Gastroenterol 16, 6035-6043

40. Valyi-Nagy T \& Dermody TS (2005) Role of oxidative damage in the pathogenesis of viral infections of the nervous system. Histol Histopathol 20, 957-967.

41. Droge W, Eck HP \& Mihm S (1994) Oxidant-antioxidant status in human immunodeficiency virus infection. Oxygen Radic Biol Syst Methods Enzymol 233, 594-601. 
42. Fuchs J, Emerit I, Levy A, et al. (1995) Clastogenic factors in plasma of HIV-1 infected patients. Free Radic Biol Med 19, 843-848.

43. Saso L \& Firuzi O (2014) Pharmacological applications of antioxidants: lights and shadows. Curr Drug Targets 15, 1177-1799.

44. Sgarbanti R, Amatore D, Celestino I, et al. (2014) Intracellular redox state as target for anti-influenza therapy: are antioxidants always effective? Curr Top Med Chem 14, 2529-2541.

45. Oda T, Akaike T, Hamamoto T, et al. (1989) Oxygen radicals in influenza-induced pathogenesis and treatment with pyran polymer-conjugated SOD. Science 244, 974-976.

46. Shi X, Shi Z, Huang H, et al. (2014) Ability of recombinant human catalase to suppress inflammation of the murine lung induced by influenza A. Inflammation 37, 809-817.

47. Gullberg RC, Jordan Steel J, Moon SL, et al. (2015) Oxidative stress influences positive strand RNA virus genome synthesis and capping. Virology 475, 219-229.

48. Lozano-Sepulveda AS, Bryan-Marrugo OL, Cordova-Fletes C, et al. (2015) Oxidative stress modulation in hepatitis $C$ virus infected cells. World J Hepatol 7, 2880-2889.

49. Gabbay E, Zigmond E, Pappo O, et al. (2007) Antioxidant therapy for chronic hepatitis $\mathrm{C}$ after failure of interferon: results of phase II randomized, double-blind placebo controlled clinical trial. World J Gastroenterol 13, 5317-5323.

50. Tian YJW, Gao N, Zhang J, et al. (2010) Inhibitory effects of glutathione on dengue virus production. Biochem Biophys Res Commun 397, 420-424.

51. Wang J, Chen Y, Gao N, et al. (2013) Inhibitory effect of glutathione on oxidative liver injury induced by dengue virus serotype 2 infections in mice. PLOS ONE 8, e55407.

52. Irlam JH, Visser MM, Rollins NN, et al. (2010) Micronutrient supplementation in children and adults with HIV infection. Cochrane Database Syst Rev, issue 12, CD003650.

53. Isanaka S, Mugusi F, Hawkins C, et al. (2012) Effect of high-dose vs standard-dose multivitamin supplementation at the initiation of HAART on HIV disease progression and mortality in Tanzania: a randomized controlled trial. JAMA 308, 1535-1544.

54. Hayek MG, Taylor SF, Bender BS, et al. (1997) Vitamin E supplementation decreases lung virus titers in mice infected with influenza. J Infect Dis 176, 273-276.

55. Han SN, Wu D, Ha WK, et al. (2000) Vitamin E supplementation increases $\mathrm{T}$ helper 1 cytokine production in old mice infected with influenza virus. Immunology 100, 487-493.

56. Ambati RR, Phang SM, Ravi S, et al. (2014) Astaxanthin: sources, extraction, stability, biological activities and its commercial applications - a review. Mar Drugs 12, 128-152.

57. Hemilä H \& Chalker E (2013) Vitamin C for preventing and treating the common cold. Cochrane Database Syst Rev, issue 1, CD000980.

58. Chen JY, Chang CY, Feng PH, et al. (2009) Plasma vitamin C is lower in postherpetic neuralgia patients and administration of vitamin $\mathrm{C}$ reduces spontaneous pain but not brush-evoked pain. Clin J Pain 25, 562-569.

59. Bresciani G, Cruz IB, de Paz JA, et al. (2013) The MnSOD Ala16Val SNP: relevance to human diseases and interaction with environmental factors. Free Radic Res 47, 781-792.

60. Levanon D, Lieman-Hurwitz J, Dafni N, et al. (1985) Architecture and anatomy of the chromosomal locus in human chromosome 21 encoding the $\mathrm{Cu} / \mathrm{Zn}$ superoxide dismutase. EMBO J 4, 77-84.

61. Folz RJ \& Crapo JD (1994) Extracellular superoxide dismutase (SOD3): tissue-specific expression, genomic characterization, and computer-assisted sequence analysis of the human EC SOD gene. Genomics 22, 162-171.

62. Lih-Brody L, Powell SR, Collier KP, et al. (1996) Increased oxidative stress and decreased antioxidant defenses in mucosa of inflammatory bowel disease. Dig Dis Sci 41, 2078-2086.

63. Mulder TP, Verspaget HW, Janssens AR, et al. (1991) Decrease in two intestinal copper/zinc containing proteins with antioxidant function in inflammatory bowel disease. Gut 32, 11461150.

64. Bełtowski J, Wójcicka G, Górny D, et al. (2000) The effect of dietary-induced obesity on lipid peroxidation, antioxidant enzymes and total plasma antioxidant capacity. I Physiol Pharmacol 51, 883-896.

65. Olusi S (2002) Obesity is an independent risk factor for plasma lipid peroxidation and depletion of erythrocyte cytoprotectic enzymes in humans. Int J Obes Relat Metab Disord 26, 1159-1166.

66. Sundaram RK, Bhaskar A, Vijayalingam S, et al. (1996) Antioxidant status and lipid peroxidation in type II diabetes mellitus with and without complications. Clin Sci (Lond) 90, 255-260.

67. Memisoğullari R, Taysi S, Bakan E, et al. (2003) Antioxidant status and lipid peroxidation in type II diabetes mellitus. Cell Biochem Funct 21, 291-296.

68. Marjani A, Moradi A \& Saeedi M (2007) Plasma lipid peroxidation zinc and erythrocyte $\mathrm{Cu}-\mathrm{Zn}$ superoxide dismutase enzyme activity in patients with type 2 diabetes mellitus in Gorgan city (south east of the Caspian Sea). J Med Sci 7, $585-590$.

69. DeRubertis F, Cravem P \& Melhem M (2007) Acceleration of diabetic renal injury in the superoxide dismutase knockout mouse: effects of tempol. Metabolism 56, 1256-1264.

70. Olofsson EM, Marklund SL \& Behndig A (2009) Enhanced diabetes-induced cataract in copper-zinc superoxide dismutasenull mice. Invest Ophthalmol Vis Sci 50, 2913-2918.

71. Yigla M, Berkovich Y \& Nagler RM (2007) Oxidative stress indices in COPD - broncho-alveolar lavage and salivary analysis. Arch Oral Biol 52, 36-43.

72. Rahman I, Swarska E, Henry M, et al. (2000) Is there any relationship between plasma antioxidant capacity and lung function in smokers and in patients with chronic obstructive pulmonary disease? Thorax 55, 189-193.

73. Stanojkovic I, Kotur-Stevuljevic J, Milenkovic B, et al. (2011) Pulmonary function, oxidative stress and inflammatory markers in severe COPD exacerbation. Respir Med 105, S31-S37.

74. Montaño M, Cisneros J, Ramírez-Venegas A, et al. (2010) Malondialdehyde and superoxide dismutase correlate with $\mathrm{FEV}_{1}$ in patients with COPD associated with wood smoke exposure and tobacco smoking. Inhal Toxicol 22, 868-874.

75. Lewandowski $\ell$, Kepinska M \& Milnerowicz H (2019) The copper-zinc superoxide dismutase activity in selected diseases. Eur J Clin Invest 49, e13036.

76. Farawela H, Khorshied M, Shaheen I, et al. (2012) The association between hepatitis $\mathrm{C}$ virus infection, genetic polymorphisms of oxidative stress genes and B-cell non-Hodgkin's lymphoma risk in Egypt. Infect Genet Evol 12, 1189-1194.

77. Ezzikouri S, El Feydi AE, Chafik A, et al. (2008) Genetic polymorphism in the manganese superoxide dismutase gene is associated with an increased risk for hepatocellular carcinoma in HCV-infected Moroccan patients. Mutat Res 649, 1-6.

78. Crawford A, Fassett RG, Geraghty DP, et al. (2012) Relationships between single nucleotide polymorphisms of antioxidant enzymes and disease. Gene 501, 89-103. 
79. Gaurav R, Varasteh JT, Weaver MR, et al. (2017) The R213G polymorphism in $S O D 3$ protects against allergic airway inflammation. JCI Insight 2, e95072.

80. Crapo JD \& Day BJ (1999) Modulation of nitric oxide responses in asthma by extracellular antioxidants. J Allergy Clin Immunol 104, 743-746.

81. Oury TD, Chang LY, Marklund SL, et al. (1994) Immunocytochemical localization of extracellular superoxide dismutase in human lung. Lab Invest 70, 889-898.

82. Kim H, Morimoto Y, Ogami A, et al. (2007) Differential expression of EC-SOD, Mn-SOD and CuZn-SOD in rat lung exposed to crystalline silica. J Occup Health 49, 242-248.

83. Yao H, Arunachalam G, Hwang JW, et al. (2010) Extracellular superoxide dismutase protects against pulmonary emphysema by attenuating oxidative fragmentation of ECM. Proc Natl Acad Sci U S A 107, 15571-15576.

84. Juul K, Tybjaerg-Hansen A, Marklund S, et al. (2004) Genetically reduced antioxidative protection and increased ischemic heart disease risk: The Copenhagen City Heart Study. Circulation 109, 59-65.

85. Banerjee M \& Vats P (2013) Reactive metabolites and antioxidant gene polymorphisms in type 2 diabetes mellitus. Redox Biol 2, 170-177.

86. Mohammedi K, Maimaitiming S, Emery N, et al. (2011) Allelic variations in superoxide dismutase-1 (SOD1) gene are associated with increased risk of diabetic nephropathy in type 1 diabetic subjects. Mol Genet Metab 104, 654-660.

87. Ascencio-Montiel Ide J, Parra EJ, Valladares-Salgado A, et al. (2013) SOD2 gene Val16Ala polymorphism is associated with macroalbuminuria in Mexican type 2 diabetes patients: a comparative study and meta-analysis. BMC Med Genet 14, 110.

88. Kegler A, Cardoso AS, Caprara ALF, et al. (2019) Involvement of $M n S O D$ Ala16Val polymorphism in epilepsy: a relationship with seizure type, inflammation, and metabolic syndrome. Gene 711, 143924

89. Wang P, Zhu Y, Xi S, et al. (2018) Association between MnSOD Val16Ala polymorphism and cancer risk: evidence from 33,098 cases and 37,831 controls. Dis Markers 2018, 3061974.

90. Luo ZC, Julien P, Wei SQ, et al. (2018) Maternal and Infant Research on Oxidative Stress (MIROS) study group. Association of pre-eclampsia with SOD2 Ala16Val polymorphism among mother-father-infant triads. Int J Gynaecol Obstet 142, 221-227.

91. Santl Letonja M, Letonja M, Ikolajević-Starcević JN, et al. (2013) Association of manganese superoxide dismutase and glutathione S-transferases genotypes with carotid atherosclerosis in patients with diabetes mellitus type 2. Int Angiol 31, 33-41.

92. National Center for Biotechnology Information (NCBI) (2020) BLAST: Basic Local Alignment Search Tool. https://blast.ncbi. nlm.nih.gov/Blast.cgi (accessed June 2020).

93. Nahon P, Sutton A, Rufat P, et al. (2009) Myeloperoxidase and superoxide dismutase 2 polymorphisms comodulate the risk of hepatocellular carcinoma and death in alcoholic cirrhosis. Hepatology 50, 1484-1493.

94. Ambrosone CB, Freudenheim JL, Thompson PA, et al. (1999) Manganese superoxide dismutase (MnSOD) genetic polymorphisms, dietary antioxidants, and risk of breast cancer. Cancer Res 59, 602-606.

95. Mitrunen K, Sillanpaa P, Kataja V, et al. (2001) Association between manganese superoxide dismutase $(M n S O D)$ gene polymorphism and breast cancer risk. Carcinogenesis 2, 827-829.

96. Egan KM, Thompson PA, Titus-Ernstoff L, et al. (2003) MnSOD polymorphism and breast cancer in a population-based casecontrol study. Cancer Lett 199, 27-33.
97. Nowell SA, Ahn J \& Ambrosone CB (2004) Gene-nutrient interactions in cancer etiology. Nutr Rev 62, 427-438.

98. Woodson K, Tangrea JA, Lehman TA, et al. (2003) Manganese superoxide dismutase $(\mathrm{MnSOD})$ polymorphism, $\alpha$-tocopherol supplementation and prostate cancer risk in the AlphaTocopherol, Beta-Carotene Cancer Prevention Study (Finland). Cancer Causes Control 14, 513-518.

99. Li H, Kantoff P, Giovannnucci E, et al. (2004) Manganese superoxide dismutase ( $M n S O D)$ polymorphism, prediagnostic plasma antioxidants and prostate cancer risk. Cancer Res 65, 2498-2504.

100. Tong SY, Lee JM, Song ES, et al. (2009) Functional polymorphism in manganese superoxide dismutase and antioxidant status: their interactions on the risk of cervical intraepithelial neoplasia and cervical cancer. Gynecol Oncol 115, 272-276.

101. Wang S, Wang F, Shi X, et al. (2009) Association between manganese superoxide dismutase (MnSOD) Val-9Ala polymorphism and cancer risk - a meta-analysis. Eur J Cancer $\mathbf{4 5}$, 2874-2881.

102. Chen Y \& Pei J (2011) Possible risk modifications in the association between MnSOD Ala-9Val polymorphism and breast cancer risk: subgroup analysis and evidence-based sample size calculation for a future trial. Breast Cancer Res Treat 125, 495-504.

103. Kakkoura MG, Demetriou CA, Loizidou MA, et al. (2016) $M n S O D$ and CAT polymorphisms modulate the effect of the Mediterranean diet on breast cancer risk among GreekCypriot women. Eur J Nutr 55, 1535-1544.

104. Da Costa LA, Badawi A \& El-Sohemy A (2012) Nutrigenetics and modulation of oxidative stress. Ann Nutr Metab 60, Suppl. 3, 27-36.

105. Kodydková J, Vávrová L, Kocík M, et al. (2014) Human catalase, its polymorphisms, regulation and changes of its activity in different diseases. Folia Biol (Praha) 60, 153-167.

106. Chistiakov DA, Savos \anov KV, Turakulov RI, et al. (2004) A new type 1 diabetes susceptibility locus containing the catalase gene (chromosome 11p13) in a Russian population. Diabetes Metab Res Rev 20, 219-224.

107. Tarnai I, Csordás M, Sükei E, et al. (2007) Effect of C111T polymorphism in exon 9 of the catalase gene on blood catalase activity in different types of diabetes mellitus. Free Radic Res 41, 806-811.

108. Watanabe Y, Metoki H, Ohkubo T, et al. (2010) Accumulation of common polymorphisms is associated with development of hypertension: a 12-year follow-up from the Ohasama study. Hypertens Res 33, 129-134.

109. Polonikov AV, Ivanov VP, Solodilova MA, et al. (2009) Tobacco smoking, fruit and vegetable intake modify association between $-21 \mathrm{~A}>\mathrm{T}$ polymorphism of catalase gene and risk of bronchial asthma. J Asthma 46, 217-224.

110. Wang IJ \& Karmaus WJ (2017) Oxidative stress-related genetic variants may modify associations of phthalate exposures with asthma. Inter J Environ Res Public Health 14, 162.

111. Ahn J, Nowell S, McCann SE, et al. (2006) Associations between catalase phenotype and genotype: modification by epidemiologic factors. Cancer Epidemiol Biomarkers Prev 15, 1217-1222.

112. Forsberg L, Lyrenas L, de Faire U, et al. (2001) A common functional C-T substitution polymorphism in the promoter region of the human catalase gene influences transcription factor binding, reporter gene transcription and is correlated to blood catalase levels. Free Radic Biol Med 30, 500-505.

113. Mak JCW, Ho SP, Yu WC, et al. (2007) Polymorphisms and functional activity in superoxide dismutase and catalase genes in smokers with COPD. Eur Respir J 30, 684-690. 
114. Zhou XF, Cui J, DeStefano AL, et al. (2005) Polymorphisms in the promoter region of catalase gene and essential hypertension. Dis Markers 21, 3-7.

115. Casp CB, She JX \& McCormack WT (2002) Genetic association of the catalase gene (CAT) with vitiligo susceptibility. Pigment Cell Res 15, 62-66.

116. Ahn J, Gammon MD, Santella RM, et al. (2005) Associations between breast cancer risk and the catalase genotype, fruit and vegetable consumption, and supplement use. Am J Epidemiol 162, 943-952.

117. Li Y, Ambrosone CB, McCullough MJ, et al. (2009) Oxidative stress-related genotypes, fruit and vegetable consumption and breast cancer risk. Carcinogenesis 30, 777-784.

118. Jansen RJ, Robinson DP, Stolzenberg-Solomon RZ, et al. (2013) Polymorphisms in metabolism/antioxidant genes may mediate the effect of dietary intake on pancreatic cancer risk. Pancreas 42, 1043-1053.

119. Sousa VC, Carmo RF, Vasconcelos LR, et al. (2016) Association of catalase and glutathione peroxidase 1 polymorphisms with chronic hepatitis C outcome. Ann Hum Genet 80, 145-153.

120. Liu Y, Xie L, Zhao J, et al. (2015) Association between catalase gene polymorphisms and risk of chronic hepatitis $\mathrm{B}$, hepatitis $B$ virus-related liver cirrhosis and hepatocellular carcinoma in Guangxi population: a case-control study. Medicine (Baltimore) 94, e702.

121. Wu X, Yuan B, López E, et al. (2014) Gene polymorphisms and chronic obstructive pulmonary disease. J Cell Mol Med 18, 15-26.

122. Chambliss JM, Ansar M, Kelley JP, et al. (2020) A polymorphism in the catalase gene promoter confers protection against severe RSV bronchiolitis. Viruses 12, 57.

123. Mak JC, Leung HC, Ho SP, et al. (2006) Polymorphisms in manganese superoxide dismutase and catalase genes: functional study in Hong Kong Chinese asthma patients. Clin Exp Allergy 36, 440-447.

124. Islam T, McConnell R, Gauderman WJ, et al. (2008) Ozone, oxidant defense genes, and risk of asthma during adolescence. Am J Respir Crit Care Med 177, 388-395.

125. Zmorzyński S, \widerska-Kołacz G, Koczkodaj D, et al. (2015) Significance of polymorphisms and expression of enzymeencoding genes related to glutathione in hematopoietic cancers and solid tumors. Biomed Res Int 2015, 853573.

126. Hurst R, Collings R, Harvey LJ, et al. (2013) EURRECA - estimating selenium requirements for deriving dietary reference values. Crit Rev Food Sci Nutr 53, 1077-1096.

127. Penney KL, Schumacher FR, Li H, et al. (2010) A large prospective study of SEP15 genetic variation, interaction with plasma selenium levels, and prostate cancer risk and survival. Cancer Prevent Res 3, 604-610.

128. Steinbrecher A, Meplan C, Hesketh J, et al. (2010) Effects of selenium status and polymorphisms in selenoprotein genes on prostate cancer risk in a prospective study of European men. Cancer Epidem Biomar 19, 2958-2968.

129. Méplan C \& Hesketh J (2014) Selenium and cancer: a story that should not be forgotten - insights from genomics. Cancer Treat Res 159, 145-166.
130. Hu YJ \& Diamond AM (2003) Role of glutathione peroxidase 1 in breast cancer: loss of heterozygosity and allelic differences in the response to selenium. Cancer Res 63, 3347-3351.

131. Nemoto M, Nishimura R, Sasaki T, et al. (2007) Genetic association of glutathione peroxidase- 1 with coronary artery calcification in type 2 diabetes: a case-control study with multi-slice computed tomography. Cardiovasc Diabetol 6, 23.

132. Zotova EV, Savost'ianov KV, Chistiakov DA, et al. (2004) Search for the association of polymorphic markers for genes coding for antioxidant defense enzymes, with development of diabetic polyneuropathies in patients with type 1 diabetes mellitus. Mol Biol (Mosk) 38, 244-249.

133. Méplan C, Crosley LK, Nicol F, et al. (2008) Functional effects of a common single-nucleotide polymorphism (GPX4c718t) in the glutathione peroxidase 4 gene: interaction with sex. Am J Clin Nutr 87, 1019-1027.

134. Combs GF, Jackson MI, Watts JC, et al. (2012) Differential responses to selenomethionine supplementation by sex and genotype in healthy adults. Br J Nutr 107, 1514-1525.

135. Jablonska E, Gromadzinska J, Reszka E, et al. (2009) Association between GPx1 Pro ${ }^{198}$ Leu polymorphism, GPx1 activity and plasma selenium concentration in humans. Eur J Nutr 48, 383-386.

136. Shuvalova YA, Kaminnyi AI, Meshkov AN, et al. (2010) Pro ${ }^{198}$ Leu polymorphism of GPx-1 gene and activity of erythrocytic glutathione peroxidase and lipid peroxidation products. Bull Exp Biol Med 149, 743-745.

137. Cardoso BR, Busse AL, Hare DJ, et al. (2016) Pro ${ }^{198}$ Leu polymorphism affects the selenium status and GPx activity in response to Brazil nut intake. Food Funct 7, 825-833.

138. Donadio JLS, Rogero MM, Cockell S, et al. (2017) Influence of genetic variations in selenoprotein genes on the pattern of gene expression after supplementation with Brazil nuts. Nutrients 9, 739.

139. Crosley LK, Bashir S, Nicol F, et al. (2013) The single-nucleotide polymorphism (GPX4C718t) in the glutathione peroxidase 4 gene influences endothelial cell function: interaction with selenium and fatty acids. Mol Nutr Food Res 57, 2185-2194.

140. Méplan C, Crosley LK, Nicol F, et al. (2007) Genetic polymorphisms in the human selenoprotein $\mathrm{P}$ gene determine the response of selenoprotein markers to selenium supplementation in a gender-specific manner (the SELGEN study). FASEBJ 21, 3063-3074.

141. Hansen RD, Krath BN, Frederiksen K, et al. (2009) GPX1 Pro ${ }^{198}$ Leu polymorphism, erythrocyte GPX activity, interaction with alcohol consumption and smoking, and risk of colorectal cancer. Mutat Res 664, 13-19.

142. Sumba PO, Kabiru EW, Namuyenga E, et al. (2010) Microgeographic variations in Burkitt's lymphoma incidence correlate with differences in malnutrition, malaria and Epstein-Barr virus. Br J Cancer 103, 1736-1741.

143. De Luca C, Kharaeva Z, Raskovic D et al. (2012) Coenzyme $\mathrm{Q}_{10}$, vitamin $\mathrm{E}$, selenuium, and methionine in the treatment of chronic recurrent viral mucocutaneous infections. Nutrition 28, 509-514. 